\title{
Contested Jurisdictions: Psychiatry, Psychoanalysis, and Clinical Psychology in the United States, 1940-2010
}

\author{
ANDREW SCULL* \\ Keywords: Psychiatry; Psychoanalysis; Clinical Psychology; \\ Jurisdictional Disputes
}

American psychiatry on the eve of Pearl Harbor was a small, stigmatised, and isolated specialty, for the most part confined as surely inside the high walls of its barrack-asylums as the patients over whom it exercised near-autocratic powers. The number of mentally ill patients incarcerated in state and county mental hospitals had grown sharply, from 150,000 at the turn of the century to 445,000 in 1940 . The fiscal crisis of the states that accompanied the Great Depression had produced a steady deterioration of conditions in these institutions, a deterioration that would intensify as a result of the exigencies of total war. In the immediate aftermath of that prolonged conflict, conditions had degenerated to such a parlous state that a number of outside observers compared America's asylums to Nazi death camps. ${ }^{1}$

Yet the size of the psychiatric profession essentially doubled during the war years, from 2,295 to almost 5,000. More importantly, the intellectual centre of gravity of the profession shifted equally dramatically. Through the 1930s, the bulk of the profession had embraced biologically reductionist accounts of mental illness. Correspondingly, they had also engaged in an orgy of experimentation with somatic treatments for mental disorder: surgical evisceration in pursuit of hypothesised septic causes of mental illness; fever therapy, first for general paralysis of the insane (or tertiary syphilis) and later for other forms of psychosis; efforts to put patients into prolonged comas, originally using barbiturates and subsequently using injections of insulin; convulsive therapies using metrazol or electricity; and direct surgical assaults on the frontal lobes of the brain. ${ }^{2}$ Led by Brigadier-General William Menninger, who had

(C) Andrew Scull, 2011.

* Andrew Scull, Distinguished Professor, Department of Sociology, University of California, San Diego, 401 Social Science Building, 9500 Gilman Drive, La Jolla, CA 92093-0533, USA.

Email: ascull@dssmail.ucsd.edu

\footnotetext{
${ }^{1}$ Alfred Maisel, 'Bedlam 1946', Life, 6 May 1946, 102-18; Albert Deutsch, The Shame of the States (New York: Harcourt Brace, 1948); Harold Orlans, 'An American Death Camp', Politics, 5, (1948), 162-7.
}

\footnotetext{
${ }^{2}$ Joel Braslow, Mental Ills, Bodily Cures (Berkeley, CA: University of California Press, 1997); Timothy Kneeland and Carol Warren, Pushbutton Psychiatry: A History of Electroshock in America (Westport, CT: Praeger, 2002); Jack D. Pressman, Last Resort: Psychosurgery and the Limits of Medicine (Cambridge: Cambridge University Press, 1998); Andrew Scull, Madhouse: A Tragic Tale of Megalomania and Modern Medicine (New Haven, CT: Yale University Press, 2005); Edward Shorter and David Healy, Shock Therapy: A History of Electroconvulsive Treatment in Mental Illness (New Brunswick, NJ: Rutgers University Press, 2007);
} 


\section{Andrew Scull}

been recruited from the psychoanalytically oriented Menninger Clinic in Topeka, Kansas, America's military psychiatrists embraced a radically different, psychodynamic approach to the problems of soldiers afflicted with what came to be called 'combat exhaustion' or 'combat neurosis'. After the war, these psychoanalytically inclined practitioners formed an aggressive new element in the profession, organising themselves through the Group for the Advancement of Psychiatry (GAP), and quickly coming to dominate the American Psychiatric Association and the higher reaches of the profession. ${ }^{3}$

That domination was aided by the initial prominence of the Menninger Clinic in the immediate post-war era in the training of a new generation of professionals, a process aided by the flow of federal dollars for the first time to support psychiatric residency programmes. Such federal largesse was part of a much larger post-war movement towards a more extensive role for the central government in training scientific and medical manpower, and in supporting scientific and medical research. It was a shift signalled by Vannevar Bush's memorandum to President Truman, Science: The Endless Frontier (1945), ${ }^{4}$ and presaged the advent of Big Science and Big Medicine, as well as the growth of the modern research university.

Psychology, too, had expanded greatly during the war years, as the mounting numbers of psychiatric casualties in the military exceeded the capacity of existing programmes to train sufficient psychiatrists. In 1940, there had been essentially no clinical psychologists. No formal training programme existed, and those few psychologists who practised in applied settings were firmly subordinated to medical men, largely confined to administering psychological instruments such as IQ tests and aptitude tests, and mostly women or Jewish or both (and thus doubly marginalised at the time). Drafted into clinical practice with combat troops, many psychologists acquired an interest in continuing such activities in the post-war period. With more than 50,000 military veterans confined in Veterans' Administration hospitals, and a further half-a-million discharged soldiers in receipt of pensions for psychiatric disabilities, not to mention a mental hospital census now climbing past half-a-million, there was ample scope for applied psychologists to move into the territory. With federal funding readily available, first from the Veterans' Administration, and from 1949, from the newly formed National Institution of Mental Health (NIMH), the major issues that emerged were the relationship of these clinical psychologists to psychiatry, and what sort of training regime the new specialty would adopt. ${ }^{5}$

Elliot Valenstein, Great and Desperate Cures (New York: Basic Books, 1986).

${ }^{3}$ Lawrence J. Friedman, Menninger: The Family and the Clinic (New York: Knopf, 1990); Gerald Grob, 'World War II and American Psychiatry', Psychohistory Review 19 (1990), 41-69; Rebecca Plant, 'William Menninger and American Psychoanalysis, 1946-48', History of Psychiatry, 16 (2005), 181-202.

\footnotetext{
${ }^{4}$ Vannevar Bush, Science: The Endless Frontier (Washington, DC: Government Printing Office, 1945).

${ }^{5}$ James H. Capshew, 'Psychology on the March: American Psychologists and World War II' (unpublished $\mathrm{PhD}$ dissertation: University of Pennsylvania, 1986); Ingrid D. Farreras, 'Before Boulder: Professionalizing Clinical Psychology, 1896-1949' (unpublished PhD dissertation: University of New Hampshire, 2001).
} 


\section{Contested Jurisdictions}

Jurisdictional disputes of this sort are a recurrent feature of the sociology of the professions. ${ }^{6}$ From Menninger on down, the psychiatric profession in the 1940s and 1950s sought to keep psychologists subordinate to medical men. During the war, military hierarchies had made this task simple to accomplish, and the bureaucratic organisation and huge size of most state hospitals seemed to offer similar advantages in the civilian sphere. But between 1945 and 1960, a sea change was occurring in the locus of psychiatric practice. Though mental hospital populations remained above half-a-million in 1960, the census had begun to decline in 1955, and the bulk of the psychiatric profession, especially the psychoanalytically oriented elements that now dominated academic psychiatry and the more prestigious and lucrative segments of professional practice, were engaged in out-patient practice. Clinical psychology was following suit, and in these outpatient settings, bureaucratic hierarchies could no longer be used to enforce disciplinary subordination.

American psychoanalysis was unique in insisting that its practice should be a medical monopoly, even in the face of an explicit opinion to the contrary by Freud himself. $^{7}$ Attempts by David Rappaport to develop a training programme for psychologists at the Menninger Clinic in 1946 had rapidly fallen foul of the insistence of the Menninger brothers that psychiatrists as medical men must always be 'the quarterback' or unquestioned leader of mental health treatment teams. ${ }^{8}$ But other psychologists quickly developed an alternative programme of professional socialisation. Codified at a meeting in Boulder, Colorado in 1949, their approach called for two years of basic training in psychological theory and research methods (including statistics), followed by intensive clinical training before being granted a $\mathrm{PhD}$. Importantly, this approach linked the emerging applied psychology: to the newly created knowledge factories that were research universities; cemented the willingness of academic psychology to support their activities (for they brought massively expanded resources to their enterprise via federal support); and gave them laboratory-based, quantitative skills that were married to expertise in research design. ${ }^{9}$ Competing with psychoanalysts who were intellectually and temperamentally disinclined to conduct large-scale experimental clinical research, this approach allowed clinical psychology to acquire the lion's share of a rapidly expanding federal research pie - in broad terms about sixty per cent of the federal dollars on offer, as opposed to the paltry five per cent captured by psychoanalysts. ${ }^{10}$

If psychiatry expanded its numbers rapidly in the post-war years, so too did clinical psychology, an expansion that in both cases relied upon large injections of federal funding. Beginning in the mid-1950s and accelerating rapidly in the following decade and a half, programmes of deinstitutionalisation decimated mental hospital populations,

\footnotetext{
${ }^{6}$ Andrew Abbott, The System of Professions (Chicago: University of Chicago Press, 1988).

${ }^{7}$ Nathan Hale, Jr (1998), The Rise and Crisis of Psychoanalysis in the United States (Oxford: Oxford University Press, 1998), Ch. 12.

${ }^{8}$ Quoted in Grob, op. cit. (note 3), 107-8.
}

\footnotetext{
${ }^{9}$ David B. Baker and Ludy T. Benjamin, Jr., 'The Affirmation of the Scientist-Practitioner: A Look Back at Boulder', American Psychologist, 55 (2000), 241-7.

${ }^{10}$ Hale, op. cit. (note 7), 252.
} 


\section{Andrew Scull}

returning the overwhelming bulk of those once confined in the back wards (and latterly those who would otherwise have been destined for such a fate) to 'the community' which most often meant to gaols and prisons, to privately run board and care homes, or to the gutter, as sidewalk psychotics became a familiar part of urban landscapes. ${ }^{11}$ So the locus of practice for psychologists and psychiatrists alike became steadily more and more skewed towards outpatient practice, a development further aided by the partial extension of health care insurance coverage to encompass treatment for mental disorders.

The psychopharmacological revolution had commenced in the mid-1950s, beginning with the introduction of the first so-called anti-psychotic drug, Thorazine, the first of many chemical 'remedies' for mental illness. For psychoanalysts, this challenge to their therapeutic approach was initially met by ignoring the drugs altogether, or by claiming that their primary purpose was to reduce florid symptomatology, thus enabling the 'real work' of psychodynamic treatment to proceed (a stance aided by the fact that the new drugs were no psychiatric penicillin, but on the contrary, at best provided a measure of symptomatic relief). Clinical psychology in those same years largely concentrated on developing short-term interventions that had statistical validation in the laboratory, and these approaches, generally labelled cognitive-behavioural therapy (CBT), formed an alternative basis around which their practice revolved. It was to clinical psychology's considerable advantage, in contrast to the lengthy and uncertain course of psychoanalytic treatment, that CBT was relatively brief and finite, lowering costs and thus greatly increasing the appeal of that approach to insurance companies.

Psychoanalysis had managed initially to contain the potential threat posed by the drugs revolution, but by the mid-1970s, that resolution was threatening to break down. Antipsychotic drugs had proved to be an enormously lucrative market, and questions were beginning to be raised in many quarters about precisely what therapeutic advantages accrued from adding seemingly interminable and expensive psychoanalytic treatments to the mix. A decade earlier, virtually every academic department of psychiatry was led by a psychoanalyst or a psychoanalytic fellowtraveller, but increasingly, the sums on offer to conduct laboratory research on potentially therapeutic compounds were exercising a powerful appeal, one bolstered by the critical importance of funded research in establishing pecking orders in large research universities.

Psychoanalysts had long disdained the Kraepelinian diagnostic categories that had emerged from within the world of the late nineteenth-century barracks-asylum. Theirs was an intellectual approach that emphasised the complexities of the individual case, and that scorned the notion that mental illnesses could be reliably and sensibly separated out into distinct forms of pathology. Analysts' persistence in this stance would prove to be a fatal strategic error. The lack of reliability and consistency in the diagnostic process had become an increasing embarrassment to the profession from the late 1960s, as it was

\footnotetext{
${ }^{11}$ Andrew Scull, Decarceration: Community Treatment and the Deviant (Englewood Cliffs, NJ: Prentice Hall, 1977); Paul Lerman,
} 


\section{Contested Jurisdictions}

exposed in the courtroom by a newly aggressive mental health bar. Perhaps more importantly, it was an ever-more serious problem for the pharmaceutical industry. Drug companies seeking new ways to profit from a burgeoning market for psychotropic substances needed homogeneous groups of patients on which to test their wares and secure regulatory approval. ${ }^{12}$ When a subset of psychiatrists who dissented from the psychoanalytic orthodoxy captured control over the seemingly arcane process of devising a new nosology of mental disorders, their psychoanalytic rivals scarcely seemed to care. By the time they saw the error of their ways, it was too late.

Publication of the 1980 edition of the Diagnostic and Statistical Manual of the American Psychiatric Association proved to be a watershed moment in the evolution of twentieth-century psychiatry. That document, and its subsequent, even more elephantine revisions, marked the advent of the so-called neo-Kraepelinian revolution in psychiatry. Embraced by the insurance industry and linked ever-more tightly to the needs and requirements of the multinational pharmaceutical industry, for whom psychotropic drugs were becoming the single most important and profitable set of products they marketed, it marked the decisive recapture of the profession by a biologically reductionist view of mental disorders. With stunning rapidity, psychoanalysis lost its apparently secure grasp on the higher reaches of the psychiatric profession. Academic departments rapidly embraced neuroscience and research on drugs. Psychoanalytic institutes, never securely linked to research universities, found themselves starved of recruits, and their brand of psychiatry faded away faster than the Cheshire Cat. By 1990, a Presidential proclamation heralded 'the decade of the brain', ${ }^{13}$ and the notion that mental disorders were the epiphenomenal manifestation of disordered neurotransmitters, faulty genes, or biochemical imbalances, was being heavily marketed to politicians and public alike.

The demand for psychotherapy continued to grow apace, particularly for milder forms of mental turmoil and distress. But it was a market largely abandoned by medics, as psychiatry tied its fortunes ever-more-tightly to the drugs revolution and systematically moved away from training neophytes in psychotherapy. Instead, it was clinical psychologists and psychiatric social workers who occupied this market niche. More heavily feminised professions, which lacked the market clout conferred by an MD degree, theirs was a cheaper and briefer treatment modality. Chafing under these limits, and conscious of how powerfully the biological accounts of mental illness have captured the public imagination, some elements within the ranks of clinical psychology

\footnotetext{
${ }^{12}$ On the unreliability of psychiatric diagnoses in the pre-DSM III era, see Aaron T. Beck, 'The Reliability of Psychiatric Diagnoses: A Critique of Systematic Studies', American Journal of Psychiatry, 119 (1962), 210-16; Aaron T. Beck, C.H. Ward, M. Mendelson, J. Mock, and J.K. Erbaugh, 'Reliability of Psychiatric Diagnoses: A Study of Consistency of Clinical Judgments and Ratings', American Journal of Psychiatry, 119 (1962), 351-7; R.E. Kendell, J.E. Cooper and A.G. Gourlay, 'Diagnostic Criteria of American and British Psychiatrists', Archives of General Psychiatry, 25 (1971), 123-30; J.R. Cooper, R. Rendell, B. Burland,
}

J. Sharpe, J. Copeland, and R. Simon, Psychiatric Diagnoses in London and New York (London: Oxford University Press, 1972); R.E. Kendell, 'The Stability of Psychiatric Diagnoses', British Journal of

Psychiatry, 124 (1974), 352-6; and - with scathing commentary and a wide array of references - Bruce J. Ennis and Thomas R. Litwack, 'Psychiatry and the Presumption of Expertise: Flipping Coins in the Courtroom', California Law Review, 62 (1974), 693-752.

${ }^{13}$ Presidential Proclamation 6158, 'The Decade of the Brain, 1990-1999', Federal Register 55 (1990), 29553. 


\section{Andrew Scull}

have sought to diminish the disadvantage they see their practices labouring under, by attempting to break the medical monopoly over the prescription of drugs to treat emotional, behavioural, and cognitive disorders. To date, they have had little real success, for their rivals know full well the importance of sustaining existing barriers to this kind of competition, and are determined to maintain the status quo. 